Europe's Journal of Psychology, 8(1), pp. 95-111, doi:10.5964/ejop.v8i1.300

www.ejop.org

\title{
Work Experiences, Satisfactions and Psychological Well-being among Women Managers and Professionals in Turkey
}

Ronald J. Burke

Schulich School of Business, York University, Toronto, Canada

Mustafa Koyuncu

Nevsehir University, Nevsehir, Turkey

Jacob Wolpin

Independent Consultant, Toronto, Canada

Abstract

Although qualified women are still underrepresented at ranks of senior management in all countries, considerable progress has been made in identifying work experiences associated with career success and advancement. The present study examines the relationship of four work experiences and work satisfactions and indicators of psychological well-being in a sample of managerial and professional women working in Istanbul Turkey. Data were collected from 143 women using anonymously completed questionnaires. Work experiences included support and encouragement, feeling accepted in the organization, opportunities for training and development, and work and family integration. Access to these four work experiences were positively and significantly correlated though the sample generally indicated low exposure to them. Hierarchical regression analyses, controlling for personal demographics and work situation characteristics, indicated that these work experiences had significant relationships with both work and well-being outcomes. Work-family integration had the strongest and most consistent relationships with these outcomes.

Keywords: Women's career advancement, Work experiences, Turkey

This is an open access article distributed under the terms of the Creative Commons Attribution License (http://creativecommons.org/licenses/by/3.0), which permits unrestricted use, distribution, and reproduction in any medium, provided the original work is properly cited. 
Women continue to enter the workforce and pursue managerial and professional careers in almost all countries (Davidson \& Burke, 2004, 2011) In addition, women now outnumber men in universities in several countries (Davidson \& Burke, 2011). Women are also achieving training and development and increasing years of work experience necessary for career advancement. Yet women seem to get stuck in middle management with few achieving senior management positions (Powell, 2011). This results in what has been termed a "glass ceiling (Barreto, Ryan, \& Schmitt, 2009; Morrison, White, \& Van Velsor, 1987, 1992), a "glass cliff" which gives women precarious positions in which it is hard to be successful (Ryan, Haslam, Hersby, Kulich, \& WilsonKovacs, 2009), a "concrete wall" keeping women in functions unlikely to lead to senior levels, or on "sticky floors".

We are beginning to understand work and career experiences that have had positive effects on women's career development (Morrison, 1992; Morrison, White, \&Van Velsor, 1987, 1992;). Morrison, White, and Van Velsor (1987) identified six factors that contributed to women's career success in a three year study of top females executives in the US. These were: help from above, a track record of achievements, a desire to succeed, an ability to manage subordinates, a willingness to take career risks, and an ability to be tough, decisive and demanding. Factors connected with not achieving expected levels of progress were: an inability to adapt, wanting too much for themselves and for other women, and .performance problems. It seemed that women had to have more assets and fewer liabilities than men to succeed.

Morrison and her colleagues (1992) also studied the work experiences of women who had advanced to senior management. Four work experiences emerged as important: being accepted by their organizations, receiving support and encouragement, having training and development opportunities, and being offered challenging work and visible assignments. These very successful women reported having more constraints and less support than when they held lower-level positions resulting in both exhaustion and still feeling stuck. Morrison (1992) observed, however, that for women, challenge typically exceeds levels of organizational support and recognition resulting in exhaustion and greater intentions to quit.

McKeen and Burke (1991), in a study of 792 Canadian women business school graduates now in managerial and professional jobs, examined the role of various work experiences in their career progress. In one sub-sample, women who participated in a greater number of education, training and developmental activities indicated greater 
job and career satisfaction, more job involvement and were more optimistic about their future career prospects. Women who were more satisfied with these experiences also reported all of the above as well as less intent to quit. McKeen and Burke reported, in a different sub-sample, relationships between career experiences and career satisfaction and career prospects. Four of these work experiences represented forms of organizational support: support and encouragement by one's organization, feeling accepted, training and development opportunities, and an absence of conflict and tension from overload and ambiguity from being a woman. Women reporting more positive work experiences in these areas also reported greater job and career satisfaction, job involvement and career optimsm and lower intention to quit. Burke (2002) also reviewed the role of developmental job experiences and developmental relationships in women's career development.

There is also evidence that offering women alternative work arrangements at particular times (e.g., child birth, caring for an aging parent) is associated with greater job and career satisfaction (Lee, Engler, \& Wright, 2002). In addition, organizational culture values more supportive of women generally (sexual harassment policies, fair treatment, due process, individual respect) $m$ have been shown to predict their levels of job satisfaction and intent to stay (Burke, 2002).

Why do managerial and professional women need particular work experiences to develop successful careers? Catalyst (1998) has identified a long list of powerful barriers to women's career advancement. These include: negative assumptions in executive ranks about women, their abilities, and their commitment to careers; perceptions that women do not fit the corporate culture; lack of career planning and the range of job experiences to fill the future needs of the organization; failure to make managers accountable for developing and advancing women; lack of mentoring and exclusion form informal career networks; and discrimination and sexual harassment, among others (see Burke \& Nelson, 2002, for others).

Burke, Koyuncu, and Fiksenbaum (2008a), in a study of 215 female managers and professionals working in a large Turkish bank, reported that women indicating greater perceptions of organizational bias favouring men reported less job satisfaction, lower levels of work engagement and more job stress; these perceptions were not related to turnover intention. Perceptions of organizational bias were also related to exhaustion but not self-reported psychosomatic symptoms. Women with more education interestingly reported higher levels of perceived organizational bias. 
Burke, Koyuncu, and Fiksenbaum (2006), examined the relationship of organizational practices designed to support women's career advancement and their work satisfaction and psychological health,. Data were collected form 186 managerial and professional women working in a large Turkish bank with offices in several cities. Five work experiences were considered: perceptions of equal treatment, support, the use of male standards, barriers facing women in their organization, and family responsibilities.

Women reporting more supportive organizational experiences and practices were also more work engaged, career satisfied and indicated higher levels of psychological health.

\section{Women in management in Turkey}

Research interest in women in management in Turkey is slowly emerging. Two related streams of writing have relevance to the status of women in management and women in the workforce in Turkey. One stream reviews the status of women in Turkey in various sectors such as students pursuing university education, women in the professions, women holding management and professional jobs, women in the public sector and women in entrepreneurship (Kabasakal, Aycan, \& Karakas, 2004; Kabasakal, Aycan, Karakas, \& Maden, 2011). These authors show that more women than men are now entering Turkish universities, but women still avoid traditional masculine fields such as engineering, technology and business management; women are increasingly entering the work force and managerial jobs but remain mostly at lower organizational levels, women fare better in professions such as teaching and health services; there is government legislation supporting gender equality but it is not clear the extent to which this legislation is monitored, women tend to fare better in the public sector than in the private sector; and very few Turkish private sector organizations develop initiatives to support the recruitment, development and advancement of women.

A second stream compares the status of women in management in Turkey with the percentages of women in these positions in other countries. The United Nations Development Programme (2008) examined these percentages in thirteen counties and found that Turkey ranked last. These data suggest that while women face challenges in pursuing managerial and professional careers in all counties, these challenges are likely greater in Turkey.

Burke and his colleagues have also undertaken studies in Turkey in which they compared males and females working in the same profession (professors, managers 
and professionals working in the tourism and hospitality sector, manufacturing managers (Burke, Koyuncu, \& Fiksenbaum, 2008b; Koyuncu, Burke, \& Fiksenbaum, 2006a, 2006b). In these studies. males and females were found to differ significantly on several personal demographic and work situation characteristics (e.g., males were older, more likely married, earned more income, were at higher organizational levels) But males and females were found to be generally similar on a range of work and wellbeing outcomes. (e.g., job satisfaction, career satisfaction, intent to quit, dimensions of work engagement).

\section{Objectives of the research}

This study, building on previous research carried out in other countries, examines the relationship of various work experiences reported by women in managerial and professional jobs in Turkey and their job and career satisfactions and psychological wellbeing. Four work experiences were considered: support and encouragement, feeling accepted by colleagues and the organization, opportunities for training and development, and work- family integration.

Three general hypotheses were examined in this research.

1. The four work experiences would be positively and significantly correlated.

2. Female managers and professionals reporting higher levels of these four work experiences would report higher levels of work satisfaction.

3. Female managers and professionals reporting higher levels of these four work experiences would report higher levels of psychological well-being.

Method

Procedure

Four organizations located in Istanbul Turkey were contacted, the purpose of the study explained, and access to women holding full time managerial and professional jobs was requested. Data were collected using anonymously completed questionnaires. The four institutions were: the Istanbul Chamber of Commerce (ICC)," the Istanbul Commodity Exchange (ICE), the Foreign Economic Relations Board (FERB) and the Economic Development Foundation (EDF). Each of these organizations has a board of directors made up mainly of men and they provide services to the business community. 
All respondents held jobs offering opportunities for promotion and were at various organizational levels (e. g., executive, director, managers, auditors, inspectors, content experts, and consultants. Respondents in the first two organizations (ICC, ICE received hard copies of the questionnaire, respondents in the other two organizations (FERB, EDF) received the questionnaire electronically. Data were collected in September through November 2011.A total of 210 females were invited to participate and 143 did so, a response rate of 68 percent. Most respondents were employed with the ICC $(79 \%)$.

\section{Respondents}

Table 1 presents demographic characteristics of the sample $(\mathrm{N}=143)$. Most were between 31 and 40 years of age (49\%), about half were married (50\%), about half had children (51\%), had a Bachelor's degree (53\%), worked 40 hours per week (68\%), earned between US\$15,000 and US\$21,999 per week (43\%), were in lower management (36\%), had supervisory duties (78\%), worked in the public sector (92\%), had been working for their organization 5 years of less (32\%) and in their present jobs between 3 to 5 years (32\%), had 6 to 10 subordinates (24\%), and worked in organizations over 100 people $(78 \%)$, these respondents working for the same large organization.

Table 1. Demographic Characteristics of the Sample

\begin{tabular}{|c|c|c|c|c|c|}
\hline$\underline{\text { Age }}$ & $\mathrm{N}$ & $\%$ & Marital status & $\mathrm{N}$ & $\%$ \\
\hline 30 or younger & 40 & 28,0 & Married & 72 & 50,3 \\
\hline $31-40$ & 70 & 48,9 & Single & 71 & 49,7 \\
\hline $41-50$ & 28 & 19,6 & & & \\
\hline \multirow[t]{2}{*}{51 or older } & 5 & 3,5 & Education & $N$ & $\%$ \\
\hline & & & High school & 24 & 16,8 \\
\hline Parental status & $N$ & $\%$ & Bachelors & 76 & 53,1 \\
\hline Have children & 73 & 51,1 & Masters & 43 & 30,1 \\
\hline \multirow[t]{2}{*}{ No children } & 70 & 48,9 & & & \\
\hline & & & $\underline{\text { Income }}$ & $\mathrm{N}$ & $\%$ \\
\hline Work hours & $\mathrm{N}$ & $\%$ & $\$ 15.000$ or less & 21 & 14,7 \\
\hline 39 or less & 5 & 3,5 & $\$ 15.000-\$ 21.999$ & 62 & 43,4 \\
\hline 40 & 97 & 67,8 & $\$ 22.000-\$ 28.999$ & 32 & 22,4 \\
\hline $41-50$ & 39 & 27,3 & $\$ 29.000$ or more & 28 & 19,6 \\
\hline 51 or more & 2 & 1,4 & & & \\
\hline
\end{tabular}


Table 1 (cont.). Demographic Characteristics of the Sample

\begin{tabular}{|c|c|c|c|c|c|}
\hline Organizational tenure & $\mathrm{N}$ & $\%$ & Organizational level & $\mathrm{N}$ & $\%$ \\
\hline 5 years or less & 46 & 32,2 & Non-management & 32 & 22,4 \\
\hline $6-10$ & 34 & 23,7 & Lower management & 52 & 36,4 \\
\hline $11-15$ & 34 & 23,8 & Middle management & 47 & 32,9 \\
\hline $16-20$ & 12 & 8,4 & Senior management & 12 & 8,4 \\
\hline \multirow[t]{2}{*}{21 or more } & 17 & 11,9 & & & \\
\hline & & & Supervisory duties & N & $\%$ \\
\hline Job Tenure & N & $\%$ & Yes & 111 & 77,6 \\
\hline $1-2$ years & 44 & 30,8 & No & 32 & 22,4 \\
\hline $3-5$ & 46 & 32,1 & & & \\
\hline $6-10$ & 23 & 16,1 & Sector & N & $\%$ \\
\hline $11-20$ & 23 & 16,1 & Private & 11 & 7,7 \\
\hline 21 or more & 7 & 4,9 & Public & 132 & 92,3 \\
\hline Organization size & N & $\%$ & Number of subordinates & N & $\%$ \\
\hline 100 or less & 31 & 21.7 & 0 & 32 & 22,4 \\
\hline \multirow[t]{6}{*}{101 or more } & 112 & 78.3 & $1-5$ & 20 & 14,0 \\
\hline & & & $6-10$ & 34 & 23,7 \\
\hline & & & $11-15$ & 14 & 9,8 \\
\hline & & & $16-20$ & 14 & 9,8 \\
\hline & & & $21-25$ & 14 & 9,8 \\
\hline & & & 26 or more & 15 & 10,5 \\
\hline
\end{tabular}

Measures

Personal demographics (e.g., age, gender, education, marital and parental status) were measured by single items.

Work situation characteristics were also measured by single items (sector, organizational level, organizational and job tenure, organizational size).

Work experiences. Four work experiences were included. These were taken from a longer scale developed and used by Burke, Koyuncu, and Fiksenbaum (2006) in an earlier study of work experiences of managerial and professional women working in 
banks in Turkey. Respondents indicated their agreement with each item on a five point Likert scale (5= strongly agree, $3=$ neither agree nor disagree. $1=$ strongly disagree).

Support and encouragement was measured by four items $(\alpha=.60)$. One item was "I have received a high level of support and encouragement in my career aspirations."

Acceptance was assessed by four items $(\alpha=.60)$. An item was "I do not feel accepted as a full-fledged member by the senior management in my organization" (reversed).

Training and development opportunities was measured by three items $(\alpha=.61)$. One item was "I am encouraged to attend training and educational programs offered within the company."

Work-family integration was assessed by two items $(\alpha=.56)$. An item was "I often feel conflict between my work role and my family or other personal commitments" (reversed).

Work outcomes. Four work outcomes were included:

Job satisfaction was measured by six items $(\alpha=.93)$ developed by Kofodimos (1993). One item was "I feel challenged by my work."

Career satisfaction was assessed by three items $(\alpha=.70)$ developed by Greenhaus, Parasuraman, and Wormley (1990). An item was "I am satisfied with the success I have had in my career"..

Career progress was also measured by a three item scale ( $\alpha=.52)$ developed by Greenhaus, Parasuraman, and Wormley (1990). One item was "I have very good prospects for promotion in this organization."

Intent to quit was measured by two items $(\alpha=.76)$ used previously by Burke (1991). An item was "Are you currently looking for a different job in a different organization? (yes/no).

Psychological well-being. Two aspects of psychological health were included.

Stress was measured by a 9 item scale $(\alpha=.80)$ developed by Spence and Robbins (1992). Respondents indicated their agreement with each item on the 
same 5 point Likert scale. A sample item was "I am under a great deal of stress at work."

Emotional exhaustion was assessed by a 9 item scale $(\alpha=.91)$ developed by Maslach, Jackson, and Leiter (1996) One item was "I feel emotionally drained from my work."

Results

Descriptive statistics

Four of the six inter-correlations between the four work experiences were positive and significantly different from zero ( $p<.05$ or greater): support and encouragement and acceptance, $r=.46$; support and encouragement and training and development opportunities ( $r$-.34), support and encouragement and work-family integration $(r=.24)$, and acceptance and work-family integration ( $r=.36)$. Training and development opportunities were uncorrelated with acceptance and work family integration ( $r s=-.02$ and .04, respectively). The mean inter-correlation among these four work experience measures was .24, $(\mathrm{p}<.01, \mathrm{n}=139)$. The means on the four work experiences were: support and encouragement, 3.2; acceptance, 2.5, training and development, 3.0, and work-family integration, 2.8, with an average mean value of 2.9 (3-neither agree nor disagree) indicating a relatively low presence of these four work experiences.

Person demographics, work situation characteristics and work experiences

Correlations were computed between thirteen personal demographic and work situation characteristics (e.g., age, marital status, income, organizational level, number of subordinates) and the four work experiences. Only four of the resulting 52 correlations $(8 \%)$ were significantly different from zero $(p<.05)$ Thus, in this sample personal and work situation characteristics were generally independent of perceptions of the four work experiences. Older managerial and professional women, those having longer organizational tenure, and those working in the private sector reported more training and development opportunities ( $r s=.18, .21$ and .20 , respectively); and managerial and professional women at higher organizational levels indicted more support and encouragement (r-.19). 
Hierarchical regression analyses

Hierarchical regression analyses were undertaken in which the various work and wellbeing outcomes were separately regressed on three blocks of predictors. The first block of predictors included four personal demographic characteristics: age, marital status, parental status, level of education. The second block of predictors included four work situation characteristics: organizational level, supervisory duties, organizational tenure, and job tenure. The third block of predictors included the four work experience measures (acceptance, support and encouragement, training and development opportunities, work and family integration). When a block of predictors accounted for a significant amount or increment $\mathrm{n}$ explained variance with a given outcome measure $(p<.05)$, individual items or measures within these blocks having significant and independent relationships with this outcome were then determined $(\mathrm{p}<.05)$. This approach controls for the relationship of both personal demographics and work situation characteristics with a given outcome before considering the relationship of the predictors of interest, in this case the measures of work and family interference.

Table 2 presents the results of hierarchical regression analyses in which the four work outcomes were separately regressed on the three blocks of predictors (personal demographics, work situation characteristics, work experiences). The following comments are offered in summary. Work experiences accounted for a significant increment in explained variance in all four analyses. Managerial and professional women reporting more training and development opportunities reported higher levels of job satisfaction ( $B=.19)$; managerial and professional women reporting more support and encouragement indicated more career satisfaction $(B=.20)$; managerial and professional women reporting higher levels of support and encouragement, and of acceptance, and work-family integration, also indicated more satisfaction (optimism) about future career prospects (Bs=.30, .22 and .19, respectively); and managerial and professional women reporting greater work-family integration also indicated less intent to quit $(B=-.22)$. 
Table 2. Work Experiences and Work Outcomes

\begin{tabular}{|c|c|c|c|c|}
\hline Work Outcomes & $\mathrm{R}$ & $R^{2}$ & $\Delta R^{2}$ & $P$ \\
\hline \multicolumn{5}{|l|}{ Job satisfaction $(n=137)$} \\
\hline Personal demographics & .20 & .04 & .04 & NS \\
\hline Work situation characteristics & .31 & .10 & .06 & NS \\
\hline Work experiences & .41 & .17 & .07 & .05 \\
\hline \multicolumn{5}{|l|}{ Training (.19) } \\
\hline \multicolumn{5}{|l|}{ Career satisfaction $(n=136)$} \\
\hline Personal demographics & .22 & .05 & .05 & NS \\
\hline Work situation characteristics & .42 & .18 & .13 & .001 \\
\hline \multicolumn{5}{|l|}{ Job tenure (-.29) } \\
\hline \multicolumn{5}{|l|}{ Supervisory duties (.31) } \\
\hline Work experiences & .53 & .28 & .10 & .01 \\
\hline \multicolumn{5}{|l|}{ Support (.20) } \\
\hline \multicolumn{5}{|l|}{ Career prospects $(n=137)$} \\
\hline Personal demographics & .20 & .04 & .04 & NS \\
\hline Work situation characteristics & .28 & .08 & .04 & NS \\
\hline Work experiences & .50 & .25 & .17 & .001 \\
\hline \multicolumn{5}{|l|}{ Acceptance (.22) } \\
\hline \multicolumn{5}{|l|}{ Work-family integration (.19) } \\
\hline \multicolumn{5}{|l|}{ Support (.30) } \\
\hline \multicolumn{5}{|l|}{ Intent to quit ( $n=138$ ) } \\
\hline Personal demographics & .24 & .06 & .06 & NS \\
\hline Work situation characteristics & .26 & .07 & .01 & NS \\
\hline Work experiences & .40 & .16 & .09 & .05 \\
\hline Work family integration (-.22) & & & & \\
\hline
\end{tabular}

Table 3 shows the results of hierarchical regression analyses in which two indicators of psychological well-being were separately regressed on the three blocks of predictors. The following comments are offered in summary. Work experiences accounted for a significant increment in explained variance in the two analyses. Managerial and professional women reporting greater work-family integration and higher levels of 
support and encouragement also indicated lower levels of exhaustion $(B s=-.40$ and -.28, respectively). Managerial and professional women reporting higher levels of work family integration also reported lower levels of stress $(B=.-.51)$.

Table 3. Work Experiences and Psychological Well-Being

\begin{tabular}{|c|c|c|c|c|}
\hline Psychological Well-Being & $\mathrm{R}$ & $R^{2}$ & $\Delta R^{2}$ & $\mathrm{P}$ \\
\hline \multicolumn{5}{|l|}{ Exhaustion $(n=132)$} \\
\hline Personal demographics & .16 & .03 & .03 & NS \\
\hline \multicolumn{4}{|l|}{ Supervisory duties (.44) } & .05 \\
\hline Work experiences & .62 & .38 & .26 & .001 \\
\hline \multicolumn{5}{|l|}{ Work-family integration (-.40) } \\
\hline \multicolumn{5}{|l|}{ Support (-.28) } \\
\hline \multicolumn{5}{|l|}{ Stress ( $n=132)$} \\
\hline Personal demographics & .22 & .05 & .05 & NS \\
\hline Work situation characteristics & .31 & .10 & .05 & NS \\
\hline Work experiences & .60 & .36 & .26 & .001 \\
\hline Work-family integration (-.51) & & & & \\
\hline
\end{tabular}

Four more general observations are worth noting. First, personal demographic factors and work situation characteristics were generally independent of perceptions of the four work experiences. Second, work experiences accounted for significant increments in explained variance in all analyses that were undertaken suggesting that these work experiences mattered to women (Tables 2 and 3). Third, support and encouragement and work-family integration were the strongest predictors of the various work outcomes (Table 2). Fourth, work-and family integration emerged as the strongest predictor of psychological well-being (see Table 3).

\section{Discussion}

These data produced considerable support for the two general hypotheses underlying this study (see Tables 2 and 3). In each of the six analyses undertaken, managerial and professional women indicating work experiences more supportive of themselves and 
their career aspirations reported more positive work and psychological well-being outcomes. Work and family integration emerged as the most common significant predictor but each of the four work experiences had significant relationships with one or more of the outcome measures.

These results were consistent with earlier observations and research findings highlighting the important role of the work environment as a factor in the satisfaction and psychological health of women in managerial and professional jobs (see Burke, 2002, for a review). The findings extend an examination of these work experiences to a sample of managerial and professional women in Turkey, not previously done before to our knowledge.

\section{Practical implications}

There is considerable room for application given the relatively low exposure of respondents in our study to all four work experiences. It has been noted that few Turkish organizations have undertaken such initiatives (Aycan, 2004; Kabasakal, Aycan, Karakas, \& Maden, 2011). Examples of best practice are offered in Catalyst (1998). Obstacles in the way of qualified women's advancement are identified. Organizations first need to identify why supporting women's career advancement and who inside the organization will spearhead the necessary system changes. Then organizations need to obtain information that will serve as a baseline to determine progress. This includes the current climate in the organization, barriers faced by qualified women in their career advancement, what is currently working well, and what are other leading edge organizations doing to attract, retain and advance qualified women. Finally organizations need to develop action plans, pilot these in small experiments, than imp them throughout the organization.

\section{Limitations of the research}

As with most research, this study has some limitations. First, all data were collected using self report surveys raising the possibility of response set biases.

Second, all data were collected at one point in time making it impossible to consider cause and effect relationships. Third, some of the measures had levels of internal consistency reliability below the generally accepted standard of .70. Fourth, the sample contained a majority of respondents working in the public sector. In addition, this sample may not be reflective of all women working in the public sector. Fifth, other work 
experiences (e.g. mentoring and networking) may also be relevant to women's career satisfaction and advancement and they were not included here.

Future research directions

Several promising research directions suggest themselves. First a qualitative study using interviews and focus groups of Turkish managerial and professional women might identify other work experiences that have developmental value. Second, it seems important to assess the career aspirations of these managerial women in future research. Work experiences are more likely to be salient for woman desirous of upward mobility.

Third, undertaking the research in private sector organizations seems appropriate. Finally, given the relatively low exposure of our sample to all four work experiences, selecting organizations that have introduced initiatives to support the advancement of women would be illuminating.

\section{Acknowledgement}

Preparation of this manuscript was supported in part by York University and Nevsehir University. Nihat Alayaglu, Istanbul Ticaret University, assisted in data collection. We thank the four organizations that participated in the data collection and our respondents.

\section{References}

Aycan, Z. (2004). Key success factors for women in management in Turkey. Applied Psychology. International Review (Steubenville, Ohio), 53, 453-477.

Barreto, M., Ryan, M. K., \& Schmitt, M. T. (2009). The glass ceiling in the $21^{\text {st }}$ century: Understanding barriers to gender equality. Washington, D.C.: American Psychological Association.

Burke, R. J. (2002). Career development of managerial women. In R. J. Burke \& D. L. Nelson (Eds.), Advancing women's careers (pp. 139-160). Oxford: Blackwell Publishing. 
Burke, R. J. (1991). Early work and career experiences of female and male managers and professionals: Reasons for optimism? Canadian Journal of Administrative Sciences, 8, 224-230. doi:10.1111/j.1936-4490.1991.tb00565.x

Burke, R. J., Koyuncu, M., \& Fiksenbaum, L. (2006). Organizational practices supportive women's career advancement and their satisfaction and well-being in Turkey. Women in Management Review, 21, 610-624. doi:10.1108/09649420610712018

Burke, R. J., Koyuncu, M., \& Fiksenbaum, L. (2008a). Still a man's world: Implications for managerial and professional women in a Turkish bank. Gender in Management: An International Journal, 23, 278-290. doi:10.1108/17542410810878086

Burke, R. J., Koyuncu, M., \& Fiksenbaum, L. (2008b). Work experiences, satisfactions and psychological well-being of female and male managers in the hospitality sector in Turkey. Equal Opportunities International, 27, 505-518. doi:10.1108/02610150810897273

Burke, R. J., \& Nelson, D. L. (Eds.). (2002). Advancing women's careers. Oxford: Blackwell Publishers.

Catalyst, inc. (1998). Advancing women in business--the Catalyst guide: Best practices from the corporate leaders. San Francisco: Jossey-Bass.

Davidson, M. J., \& Burke, R. J. (2004). Women in management worldwide: Facts, figures and analysis. Aldershot: Ashgate Publishisng.

Davidson, M. J., \& Burke, R. J. (2011). Women in management worldwide: Progress and prospects (2nd ed.). Surrey: Gower Publishing.

Greenhaus, J. H., Parasuraman, S., \& Wormley, W. (1990). Organizational experiences and career success of black and while managers. Academy of Management Journal, 33, 64-86. doi:10.2307/256352

Kabasakal, H., Aycan, Z., \& Karakas, F. (2004). Women in management in Turkey. In M. J. Davidson \& R. J. Burke (Eds.), Women in management worldwide: Facts, figures and analysis (pp. 273-293). Adlershot: Ashgate Publishing.

Kabasakal, H., Aycan, Z., \& Karakas, F. \& Maden, C. (2011). Women in management in Turkey. In M. J. Davidson \& R J. Burke (Eds.), Women in management worldwide: Progress and Prospects (2nd ed, pp 317-339). Surrey: Gower Publishing. 
Kofodimos, J. (1993). Balancing act. San Francisco: Jossey-Bass.

Koyuncu, M., Burke, R. J., \& Fiksenbaum, L. (2006a). Work experiences and satisfactions of male and female professors in turkey: Signs of progress? Equal Opportunities International, 25, 38-47. doi:10.1108/02610150610645959

Koyuncu, M., Burke, R. J., \& Fiksenbaum, L. (2006b). Work engagement among women managers and professionals in a Turkish bank: Potential antecedents and consequences. Equal Opportunities International, 25, 299-310. doi:10.1108/02610150610706276

Lee, M. D., Engler, L., \& Wright, L. (2002). Exploring the boundaries in professional careers: Reduced workload arrangements in law, medicine, and accounting. In R. J. Burke \& D. L. Nelson (Eds.), Advancing women's careers (pp. 174-205). Oxford: Blackwell Publishers.

Maslach, C., Jackson, S. E., \& Leiter, M. P. (1996). Maslach Burnout Inventory. (3rd ed.). Palo Alto, CA: Consulting Psychologists Press.

McKeen, C. A., \& Burke, R. J. (1991). Work experiences and career success of managerial and professional women: Study design and preliminary findings. Canadian Journal of Administrative Sciences, 8, 251-258. doi:10.11 11/j.1936-4490.1991.tb00569.x Morrison, A. M. (1992). The new leaders. San Francisco: Jossey-Bass.

Morrison, A. M., White, R. P., \& Van Velsor, E. (1987). Breaking the glass ceiling. Reading, MA.: Addison-Wesley.

Morrison, A. M., White, R. P., \& Van Velsor, E. (1992). Breaking the glass ceiling (updated version). Reading, MA.:Addison-Wesley.

Powell, G. N. (2011). Women and men in management. Thousand Oaks, CA: Sage Publications.

Ryan, M. K., Haslam, A., Hersby, M. D., Kulich, C., \& Wilson-Kovacs, D. (2009). The stress of working on the edge: Implications of glass cliffs for both women and organizations. In $M$. Barreto, M. K. Ryan, \& M. T. Schmitt (Eds.), The glass ceiling in the $21 x t$ century: Understanding barriers to gender equality (pp. 153-170). Washington, D. C.: American Psychological Association.. 
Spence, J. T., \& Robbins, A. S. (1992). Workaholsm: Definition, measurement and preliminary results. Journal of Personality Assessment, 58, 160-178.

doi:10.1207/s15327752jpa5801_15

United Nations Development Programme. (2008). Human development report 20072008. New York: Oxford University Press.

About the authors

Ronald J. Burke is currently Professor of Organizational studies, Schulich School of Business, York University. His research interests in clued human resource practices and organizational performance, and women in management

Ronald J. Burke, W363, Schulich School of Business, York University, 4700 Keele Street, Toronto Ontario M3J 1P3, Canada, E-mail: rburke@schulich.yorku.ca

Mustafa Koyuncu is currently Associated Professor in the School of Tourism and Hospitality, Nevsehir University in Turkey. His research interests include management development in the tourism and hospitality sector, and hospitality management education more generally.

Jacob Wolpin is an independent consultant in Toronto. His research interests include understanding an aging workforce and organizational restructuring and downsizing. 